\title{
AKADEMI KOMUNITAS DAN PENERAPAN MASTER PLAN PERLUASAN DAN PERCEPATAN PEMBANGUNAN EKONOMI INDONESIA (MP3EI)
}

\author{
Iskandar Agung \\ e-mail: rusnah_syarif@yahoo.co.id \\ Puslitjak Balitbang Kemdikbud
}

\begin{abstract}
Abstrak: Pendirian AK berupa pendidikan vokasi setingkat diploma satu dan/atau diploma dua yang tertuang dalam UU No. 12/2012 pas. 59 merupakan upaya meningkatkan Angka Partisipasi Kasar (APK) ke perguruan tinggi (PT), pengembangan kualitas Sumberdaya Manusia (SDM), serta memberikan peluang bagi daerah untuk memiliki perguruan tinggi negeri. Di samping itu pendirian AK diharapkan dapat mendukung penerapan perluasan dan pertumbuhan ekonomi daerah, seperti yang tertuang dalam konsep MP3El yang dicetuskan oleh pemerintah. Namun dari hasil kajian diperoleh, pendirian AK masih menuai permasalahan dalam penentuan program studi, ketepatan penunjukkan lokasi dan penyelenggaraan program studi, serta pola pembinaan dan hubungan kerja. Tulisan ini menelaah secara kritis berbagai masalah tersebut dan menyarankan (a) perlunya upaya pengkajian yang mendalam dan cermat dalam menentukan program studi pada PDD/AK; (b) meniadakan pendirian AK type 'penugasan', tetapi membuka kesempatan untuk pihak swasta berpartisipasi terhadap penyelenggaraan AK; (c) mengalihkan program studi yang diselenggarakan AK ke program studi lain di daerah tertentu; (d) merubah pola penyaluran anggaran ke pemerintah daerah setempat; dan (e) membentuk wadah atau tim kerja khusus yang bertanggungjawab langsung kepada Mendikbud.
\end{abstract}

Kata-kata kunci: akademi komunitas, program studi, pembangunan ekonomi, hubungan kerja.

\section{COMMUNITY ACADEMY AND APPLICATION OF MASTER PLAN EXPANSION AND INDONESIA ECONOMIC DEVELOPMENT ACCELERATION}

\begin{abstract}
The establishment of Community Academy (CA) as a vocational education diploma one and/or two stipulated in Law No. 12/2012 fit 59 is an effort to increase the Gross Enrollment Ratio (GER) for higher education (HE), to develop human resource quality, and to provide an opportunity for the region to have a public university. In addition, the establishment of CA is expected to support the implementation and expansion of regional economic growth, as set out in the MP3EI concept initiated by the government. However, the results obtained by the study, the establishment of CA is still reaping a number of problems related to determining the course, the accuracy of the location of the appointment and organization of the study program, and the pattern of development and the ongoing working relationship. Having critically analyzed the problems, this article recommends to (a) conduct an in-depth and thorough assessment to determine the program of study in CA; (b) negotiate the establishment of CA with 'assignment' type and provide the opportunities for private sector CA to participate; (c) substitute the courses conducted by CA in certain regions ; (d) change the distribution budgent patterns: and (e) set a special teamwork responsible directly to the Minister of Education and Culture.
\end{abstract}

Keywords: community academy, program study, economic development, working relationship.

\section{PENDAHULUAN}

Pendirian Akademi Komunitas (AK) merupakan amanat yang tertuang dalam UU No. 12/2012, khususnya pasal 59. Pendirian ini erat kaitannya dengan upaya meningkatkan Angka Partisipasi Kasar (APK) lulusan pendidikan menengah ke jenjang pendidikan yang lebih tinggi, sekaligus meningkatkan kemampuan dan keterampilan tenaga kerja guna mendukung percepatan pembangunan ekonomi Indonesia. Angka Partisipasi Kasar (APK) ke PT memang masih tergolong 68 Jurnal IImiah VISI P2TK PAUD NI - Vol. 9, No.1, Juni 2014 rendah, dan merupakan salah satu isu strategis yang perlu di atasi oleh pemerintah. Peningkatan APK PT bermakna tantangan dan tuntutan untuk meningkatkan kualitas dan daya saing sumber daya manusia (SDM), terutama dalam menghadapi situasi global yang ditandai dengan iklim kompetitif yang semakin ketat antar bangsa di dunia. Hanya dengan pemilikan kualitas dan daya saing SDM yang tinggi suatu bangsa dapat bersaing dan merebut sumber daya yang terba- 
tas, serta menarik manfaat guna meningkatkan taraf hidup mereka.

Tabel 1. Perkembangan APK (\%)

\begin{tabular}{|c|c|c|c|}
\hline $\begin{array}{c}\text { PARTISIPASI PENDIDI- } \\
\text { KAN FORMAL }\end{array}$ & $\mathbf{2 0 0 9}$ & $\mathbf{2 0 1 0}$ & $\mathbf{2 0 1 1}$ \\
\hline $\begin{array}{c}\text { Angka Partisipasi Kasar (APK) } \\
\text { SD/MI }\end{array}$ & 110.35 & 111.63 & 102.44 \\
\hline $\begin{array}{c}\text { Angka Partisipasi Kasar (APK) } \\
\text { SMP/MTs }\end{array}$ & 81.09 & 80.35 & 89.09 \\
\hline $\begin{array}{c}\text { Angka Partisipasi Kasar (APK) } \\
\text { SM/MA }\end{array}$ & 62.37 & 62.53 & 63.86 \\
\hline Angka Partisipasi Kasar (APK) PT & 14.59 & 16.35 & 17.28 \\
\hline
\end{tabular}

*Sumber: Biro Pusat Statistik, dalam Gumelar, 2012.

Kondisi kualitas SDM Indonesia, terutama apabila dikaitkan dengan ketenagakerjaan, memang mendesak untuk diperhatikan dan dicarikan segera upaya peningkatannya. Data yang dipublikasikan oleh United Nation Development Programme (UNDP) tahun 2012 memang memperlihatkan adanya perbaikkan angka indeks kualitas SDM (Human Development Index-HDI) yang berada pada urutan 121 dari 186 negara di dunia dan terkategori sebagai kelompok medium human development (UNDP, 2012) Namun jelas angka indeks tersebut masih jauh dari harapan, dan terus-menerus harus ditingkatkan. Dibanding dengan negara tetangga seperti Malaysia, Thailand, Singapura, dan lain-lainnya, posisi HDI Indonesia berada di bawah posisi HDI bangsa-bangsa tersebut. Di sisi lain data pula memperlihatkan, bahwa dari angkatan kerja Indonesia keseluruhan tercatat sebanyak $53 \%$ terkategori tidak berpendidikan, $34 \%$ memiliki tingkat pendidikan sebatas pendidikan dasar, $11 \%$ berpendidikan menengah, dan hanya 2 (dua) \% yang memiliki latarbelakang pendidikan tinggi (Suyanto, 2006).

Guna mendorong peningkatan angka partisipasi lulusan SLTA ke perguruan tinggi serta keterampilan tenaga kerja, pemerintah telah mengeluarkan UU No. 12/2012 tentang Pendidikan Tinggi yang salah satu pasal di dalamnya (pasal 59) mengemukakan adanya pendirian dan penyelenggaraan Akademi Komunitas. Pendirian AK ditujukan untuk penyelenggaraan pendidikan vokasi atau kejuruan setingkat D-1 dan D-2, yang akan diintegrasikan pula dengan upaya percepatan dan perluasan pembangunan ekonomi. Tujuan yang ingin dicapai, antara lain upaya meningkatkan kualitas SDM dan tenaga kerja, optimalisasi pemanfaatan potensi ekonomi daerah, menciptakan peluang kerja, menumbuhkan semangat kewiraswastaan, mendorong percepatan pembangunan, serta meningkatkan pertumbuhan ekonomi daerah dan nasional.

Tulisan ini selanjutnya bermaksud membahas mengenai pendirian dan penyelenggaraan AK di sejumlah daerah. Tulisan bertujuan untuk menilai keselarasan program studi yang diselenggarakan oleh AK dengan pengembangan potensi ekonomi daerah dalam konteks penerapan konsep MP3EI, ketepatan penunjukkan lokasi dan penyelenggaraan program studi, serta mengkaji pola hubungan yang terjalin antara AK dengan perguruan tinggi pembina. Tulisan merupakan sebagian hasil penelitian Pusat Penelitian Kebijakan, Balitbang-Kemdikbud di tahun 2013 lalu.

\section{A. Pendidikan, Ketenagakerjaan, dan Pembangu- nan Ekonomi}

Pendidikan merupakan kata yang sering dianggap sebagai cara strategis untuk merubah kehidupan suatu masyarakat. Inti pendidikan adalah penanaman nilai, dan dengannya manusia dapat menggunakan untuk mengenal, memahami, menafsirkan, mengelola, mengembangkan, dan memanfaatkan lingkungan sekitarnya. Dalam konteks penyelenggaraan sistem pendidikan nasional, istilah pendidikan dimaknai sebagai usaha sadar dan terencana untuk mewujudkan suasana belajar dan proses pembelajaran agar peserta didik secara aktif mengembangkan potensi dirinya untuk memiliki kekuatan spritual keagamaan, pengendalian diri, keperibadian, kecerdasan, akhlak mulia, serta keterampilan yang diperlukan dirinya, masyarakat, bangsa, dan negara (UU No. 20/2003; pasal 1:1). Definisi ini menyiratkan, bahwa penyelenggaraan sistem pendidikan nasional merupakan tindakan disengaja untuk membentuk, membina, dan mengembangkan sumber daya manusia yang berkualitas, mandiri, unggul, dan kompetitif. Sumber daya manusia Indonesia seperti itu diharapkan memiliki kemampuan untuk menguasai, mengembangkan, mengelola, dan memanfaatkan ilmu pengetahuan dan teknologi untuk menjawab berbagai tantangan yang dihadapi.

Dalam era modern, pendidikan memberikan sumbangsih nyata terhadap perkembangan ekonomi. Pendidikan menjadi faktor utama dalam menyiapkan kemampuan dan keterampilan tenaga kerja. Pendekatan ketenagakerjaan ini telah lama dikemukakan oleh Vaizey (1987), Denisson (1962), Schultz (1963), Harbison dan Myers (1964) dalam membicarakan hubungan antara pendidikan dan ekonomi. Kepandaian dan keterampilan seorang atau lebih pekerja merupakan hasil dari pendidikan dan pelatihan formal. Makin pandai dan terampil pekerja menggunakan teknik produksi, makin besar kemungkinannya untuk memberikan sumbangan maksimal bagi produktivitas. Pendidikan memberikan dan mengembangkan kapasitas pekerja, yang pada akhirnya berpengaruh terhadap perkembangan dan pertumbuhan ekonomi. Dengan kata lain, tinggi atau 
rendahnya latar belakang pendidikan yang dimiliki oleh tenaga kerja suatu negara akan menentukan tingkat perkembangan dan pertumbuhan ekonomi negara yang bersangkutan.

Atas dasar itu, upaya meningkatkan kemampuan dan keterampilan tenaga kerja pun menjadi isu yang perlu diperhatikan dalam pembangunan dan pertumbuhan ekonomi suatu negara, termasuk Indonesia. Realitanya, meski dari tahun ke tahun Indonesia mencapai pertumbuhan ekonomi di atas angka 6,0 $\%$, kualitas tenaga kerja kita masih tergolong rendah. Sementara pihak beranggapan, rendahnya kualitas tenaga kerja yang dimiliki Indonesia disebabkan oleh penyelenggaraan pendidikan yang mencerminkan kondisi yang memprihatinkan pula. PERC tahun 2001 pernah mempublikasikan hasil survei yang mencerminkan rendahnya kualitas pendidikan di Indonesia, dibanding dengan negara-negara lain di Asia. Survei ini bertujuan untuk melihat profil kualitas tenaga kerja, dengan asumsi untuk mendapatkan tenaga kerja yang berkualitas diperlukan sistem pendidikan yang baik, dan sebaliknya. Dengan rentang skor 0 - 10 yang menunjukkan pergerakkan kriteria skor rendah yang tergolong baik ke skor tinggi yang tergolong jelek/ buruk, Indonesia berada di posisi skor 6,56 yang sekaligus cenderung menunjukkan penilaian berkualitas rendah (jelek/buruk).

Data pula mencerminkan bahwa sebagian besar tenaga kerja Indonesia masuk dalam kategori tidak berpendidikan yang mengisi pekerjaan di sektor pertanian tradisional, jasa buruh, pedagang kecil, dan sebagainya. Di sektor industri (manufacturing dan jasa), sebagian besar tenaga kerja masih terkategori berpendidikan dasar dan menengah, dan hanya sebagian kecil saja yang terkategori berpendidikan tinggi. Harapan yang terkandung, kondisi pendidikan tenaga kerja dapat ditingkatkan sejalan dengan upaya peningkatan kualitas sumber daya manusia Indonesia dalam menghadapi tantangan global di abad 21 ini. Iklim kompetitif yang kian tajam antar bangsa dalam memperebutkan sumber daya yang terbatas, mau tidak mau menuntut peningkatan kualitas tenaga kerja Indonesia apabila ingin berkiprah dan memetik manfaat dari situasi itu untuk meningkatkan kesejahteraan hidup.

Sulit disangkal bahwa pendidikan memiliki peran strategis dalam meningkatkan kualitas dan daya saing bangsa Indonesia. Indonesia telah menyadari hal itu, dan sejak lama meletakkan prioritas dan kebijakannya untuk meningkatkan kualitas SDM dalam pembangunan bidang pendidikan. Arah kebijakan pendidikan tidak lagi bertumpu pada masalah pemerataan dan perluasan akses pendidikan, tetapi juga memberi penekanan pada masalah peningkatan mutu, relevansi, dan daya saing. Upaya peningkatan mutu pendidikan diharapkan mampu meningkatkan dan membentuk tenaga terdidik, terampil, memiliki relevansi tinggi dengan kebutuhan masyarakat (dan industri), memiliki daya saing untuk merebut peluang yang ada, serta bermanfaat untuk mendorong pertumbuhan ekonomi.

\section{B. MP3EI}

Selama lebih dari enam dasawarsa, Indonesia telah mengalami kemajuan yang cukup pesat di bidang pembangunan ekonomi. Kemajuan ekonomi telah membawa peningkatan kesejahteraan masyarakat, yang salah satunya tercermin dalam peningkatan pendapatan per kapita. Meski demikian, kenyataan memperlihatkan bahwa tantangan ke depan pembangunan ekonomi Indonesia semakin kompleks dan tidak mudah di atasi. Dinamika ekonomi domestik dan global mengharuskan Indonesia senantiasa siap terhadap perubahan dan perkembangan lingkungan, baik lingkup nasional, regional, maupun global. Keberadaan Indonesia di pusat gravitasi baru ekonomi global, yaitu kawasan Asia Timur dan Asia Tenggara, mengharuskan Indonesia harus mempersiapkan diri lebih baik lagi untuk mempercepat terwujudnya suatu negara maju. Selaras dengan visi pembangunan nasional sebagaimana tertuang dalam UU No. 17/2007 Tentang Rencana Pembangunan Jangka Panjang Nasional 2005-2025, maka dikeluarkan Master Plan Percepatan dan Perluasan Pembangunan Ekonomi Indonesia (MP3EI) dengan visi utama: (1) peningkatan nilai tambah dan perluasan rantai nilai proses produksi serta distribusi dari pengelolaan aset dan akses SDA, geografis wilayah, dan SDM, melalui penciptaan kegiatan ekonomi yang terintegrasi dan sinergis di dalam maupun antar-kawasan pusat-pusat pertumbuhan ekonomi; (2) mendorong terwujudnya peningkatan efisiensi produksi dan pemasaran serta integrasi pasar domestik dalam rangka penguatan daya saing dan daya tahan perekonomian nasional; dan (3) mendorong penguatan sistem inovasi nasional di sisi produksi, proses, maupun pemasaran untuk penguatan daya saing global yang berkelanjutan, menuju innovation-driven economy.

Melalui penerapan MP3El diharapkan terjadi percepatan dan perluasan pembangunan ekonomi sehingga Indonesia dapat mencapai sebagai negara maju pada tahun 2025 dengan pendapatan per kapita yang berkisar antara USD 14.250 - USD 15.500 dengan nilai total perekonomian (PDB) berkisar antara USD 4,0 - 4,5 triliun. Perwujudannya semua itu memerlukan pertumbuhan ekonomi riil sebesar 6,4 - 7,5 
\% pada periode 2011 - 2014, dan sekitar 8,0 - 9,0\% pada periode 2015 - 2025. Pertumbuhan ekonomi tersebut akan dibarengi oleh penurunan inflasi dari sebesar $6,5 \%$ pada periode 2011 - 2014 menjadi 3,0
$\%$ pada 2025. Kombinasi pertumbuhan dan inflasi seperti itu mencerminkan karakteristik negara maju dilihat pada gambar 1 .

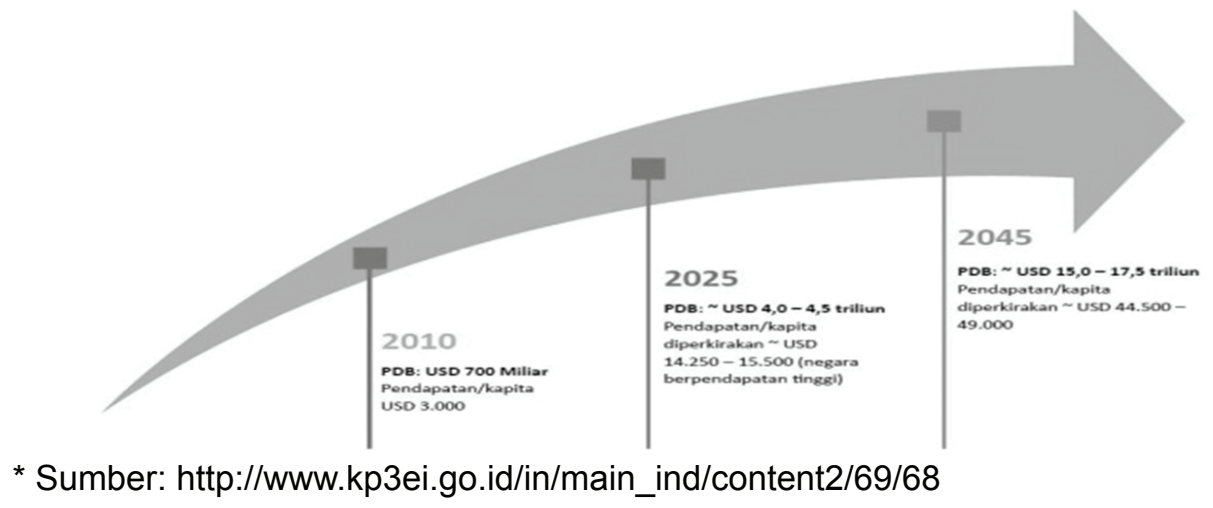

Gambar 1. Kombinasi pertumbuhan dan inflasi

Untuk merealisasikan MP3EI telah dibentuk Komite Percepatan dan Perluasan Pembangunan Ekonomi Indonesia (KP3EI) 2011 - 2025 oleh Presiden Republik Indonesia pada 20 Mei 2011. Lembaga yang diketuai oleh Presiden RI ini dibentuk berdasarkan Perpres No. 32/2011 Pasal 4 Tentang Master plan Percepatan dan Perluasan Pembangunan Ekonomi Indonesia 2011-2025(MP3EI). Tugas-tugas KP3EI adalah (1) melakukan koordinasi perencanaan dan pelaksanaan MP3EI; (2) melakukan pemantauan dan evaluasi terhadap pelaksanaan MP3El; dan (3) menetapkan langkah-langkah dan kebijakan dalam rangka penyelesaian permasalahan dan hambatan pelaksanaan MP3EI.

Strategi utama dalam merealisasikan MP3EI, antara lain:

1. Peningkatan Potensi Ekonomi Wilayah Melalui Koridor Ekonomi

MP3El diselenggarakan berdasarkan pendekatan pengembangan pusat-pusat pertumbuhan ekonomi, baik yang telah ada maupun yang baru. Pendekatan ini pada intinya merupakan integrasi dari pendekatan sektoral dan regional. Setiap wilayah mengembangkan produk yang menjadi keunggulannya. Tujuan pengembangan pusat pertumbuhan ekonomi tersebut adalah untuk memaksimalkan keuntungan aglomerasi, menggali potensi dan keunggulan daerah serta memperbaiki ketimpangan spasial pembangunan ekonomi Indonesia. (http://www.kp3ei. go.id/in/main_ind/ content2/69/83)

Pengembangan pusat-pusat pertumbuhan dilakukan dengan mengembangkan koridor-koridor ekonomi, yaitu:

a. Koridor Ekonomi Sumatera

Koridor Ekonomi Sumatera mempunyai tema
Sentra Produksi dan Pengolahan Hasil Bumi dan Lumbung Energi Nasional. Kegiatan ekonomi utama yang dikembangkan, antara lain: perkebunan kelapa sawit, perkebunan karet, tambang batubara, perkapalan, besi baja, dan Kawasan Strategis Nasional (KSN) Selat Sunda. Selain kegiatan ekonomi utama yang menjadi fokus Koridor Ekonomi Sumatera tersebut, di koridor ini juga akan dikembangkan beberapa kegiatan ekonomi yang dinilai mempunyai potensi, seperti Pertanian Pangan, Pariwisata, Migas, Perkayuan, dan Perikanan. Adapun untuk mengamankan ketersediaan produksi pangan dilakukan pengembangan lumbung pangan di Aceh.

b. Koridor Ekonomi Jawa

Pengembangan Koridor Ekonomi Jawa mempunyai tema Pendorong Industri dan Jasa Nasional. Fokus pembangunan ekonomi Koridor Ekonomi Jawa adalah pada kegiatan ekonomi utama makananminuman, tekstil, dan peralatan transportasi. Selain itu terdapat pula aspirasi untuk mengembangkan kegiatan ekonomi utama perkapalan, telematika, dan alat utama sistem senjata (alutsista). Percepatan dan perluasan perekonomian di Koridor Ekonomi Jawa diharapkan dapat memperkuat posisi Koridor Ekonomi Jawa sebagai "Pusat Pengembangan Industri dan Jasa Nasional" dan memberikan efek positif bagi pengembangan Koridor lainnya.

c. Koridor Ekonomi Bali - Nusa Tenggara

Pengembangan Koridor Ekonomi Bali-Nusa Tenggara mempunyai tema Pintu Gerbang Pariwisata dan Pendukung Pangan Nasional. Pembangunan kepariwisataan di Koridor Ekonomi Bali - Nusa Tenggara difokuskan pada 9 (sembilan) destinasi Pariwisata Nasional. Dalam mengembangkan pendukung ketahanan pangan nasional, di koridor Bali - Nusa Tenggara Jurnal IImiah VISI P2TK PAUD NI - Vol. 9, No.1, Juni 2014 
dikembangkan kegiatan ekonomi utama perikanan. Kegiatan perikanan juga mencakup produk kelautan, misalnya seperti rumput laut dan garam. Di samping itu dikembangkan pula kegiatan ekonomi utama peternakan. Jenis populasi ternak yang paling potensial dikembangkan di koridor ini adalah Sapi Bali.

\section{d. Koridor Ekonomi Kalimantan}

Keberadaan Koridor Ekonomi Kalimantan merupakan salah satu pilar penompang ekonomi bangsa, dan menjadi basis kekuatan ekonomi nasional. Koridor ini ditetapkan sebagai pilar energi nasional, terutama mengingat kandungan potensi sumberdaya migas dan batubara yang ada di wilayah ini. Selain itu, koridor ekonomi Kalimantan juga menyimpan kekayaan alam yang berpotensi untuk dikembangkan, seperti besi baja, bauksit, kelapa sawit, dan perkayuan.

\section{e. Koridor Ekonomi Sulawesi}

Tema pembangunan untuk Koridor Ekonomi Sulawesi adalah Pusat Produksi dan Pengolahan Hasil Pertanian, Perkebunan, Perikanan, Migas, dan Pertambangan Nasional. Pembangunan Koridor Ekonomi Sulawesi berfokus pada kegiatan-kegiatan ekonomi utama Pertanian Pangan (beras dan jagung), Kakao, Perikanan, Nikel, serta Minyak dan Gas.

\section{f. Koridor Ekonomi Papua - Kepulauan Maluku}

Tema pembangunan Koridor Ekonomi Papua dan Kepulauan Maluku adalah sebagai Pusat Pengembangan Pangan, Perikanan, Energi, dan Pertambangan Nasional. Strategi pembangunan ekonomi Koridor Ekonomi Papua dan Kepulauan Maluku difokuskan pada 5 kegiatan Ekonomi utama, yaitu Pertanian Pangan - MIFEE (Merauke Integrated Food \& Energy Estate), Tembaga, Nikel, Migas, dan Perikanan.

Pembangunan koridor ekonomi ini juga dapat diartikan sebagai pengembangan wilayah untuk menciptakan dan memberdayakan basis ekonomi terpadu dan kompetitif serta berkelanjutan. MP3EI melalui pembangunan koridor ekonomi memberikan penekanan baru bagi pembangunan ekonomi wilayah, sebagai berikut: Pertama, di arahkan pada pembangunan yang menekankan pada peningkatan produktivitas dan nilai tambah pengelolaan sumber daya alam melalui perluasan dan penciptaan rantai kegiatan dari hulu sampai hilir secara berkelanjutan. Kedua, di arahkan pada pembangunan ekonomi yang beragam dan inklusif, dan dihubungkan dengan wilayah-wilayah lain di luar koridor ekonomi, agar semua wilayah di Indonesia dapat berkembang sesuai dengan potensi dan keunggulan masing-masing wilayah.

Ketiga, menekankan pada sinergi pembangunan sektoral dan wilayah untuk meningkatkan keunggulan komparatif dan kompetitif secara nasional, regional maupun global. Keempat, menekankan pembangunan konektivitas yang terintegrasi antara sistem transportasi, logistik, serta komunikasi dan informasi untuk membuka akses daerah. Kelima, didukung dengan pemberian insentif fiskal dan non-fiskal, kemudahan peraturan, perijinan dan pelayanan publik dari pemerintah pusat maupun daerah.

\section{Penguatan Konektivitas Nasional}

Suksesnya pelaksanaan perluasan dan percepatan pembangunan ekonomi Indonesia sangat tergantung pada kuatnya derajat konektivitas ekonomi nasional (intra dan inter wilayah) maupun konektivitas ekonomi internasional Indonesia dengan pasar dunia. Dengan pertimbangan tersebut Masterplan Percepatan dan Perluasan Pembangunan Ekonomi Indonesia (MP3EI) menetapkan penguatan konektivitas nasional sebagai salah satu dari tiga strategi utama (pilar utama). Konektivitas Nasional merupakan pengintegrasian 4 (empat) elemen kebijakan nasional yang terdiri dari Sistem Logistik Nasional (Sislognas), Sistem Transportasi Nasional (Sistranas), Pengembangan wilayah (RPJMN/RTRWN), dan Teknologi Informasi dan Komunikasi (TIK/ICT).

Tujuan Penguatan Konektivitas Nasional adalah (1) menghubungkan pusat-pusat pertumbuhan ekonomi utama untuk memaksimalkan pertumbuhan berdasarkan prinsip keterpaduan, inter-modal supply chains systems; (2) memperluas pertumbuhan ekonomi melalui peningkatan aksesibilitas dari pusat-pusat pertumbuhan ekonomi ke wilayah belakangnya (hinterland); dan (3) menyebarkan manfaat pembangunan secara luas (pertumbuhan yang inklusif dan berkeadilan) melalui peningkatan konektivitas dan pelayanan dasar ke daerah tertinggal, terpencil dan perbatasan dalam rangka pemerataan pembangunan.

3. Penguatan Kemampuan SDM dan IPTEK Nasional

Peningkatan kemampuan SDM dan IPTEK Nasional menjadi salah satu dari 3 (tiga) strategi utama pelaksanaan MP3EI. Dalam era ekonomi berbasis pengetahuan, mesin pertumbuhan ekonomi sangat bergantung pada kapitalisasi hasil penemuan menjadi produk inovasi. Dalam konteks ini, peran sumberdaya manusia yang berpendidikan menjadi kunci utama dalam mendukung pertumbuhan ekonomi yang berkesinambungan. Oleh karena itu, tujuan utama di dalam sistem pendidikan dan pelatihan untuk mendukung hal tersebut di atas haruslah bisa menciptakan sumberdaya manusia yang mampu beradaptasi dengan cepat terhadap perkembangan sains dan teknologi.

\section{Akademi Komunitas}

Sumberdaya manusia Indonesia yang berkuali- 
tas, berdaya saing, dan produktif dapat menjadi penggerak utama pertumbuhan ekonomi. Hal ini sejalan dengan hasil berbagai studi yang sampai pada kesimpulan, bahwa kemampuan dan keterampilan tenaga kerja yang tinggi menjadi faktor penting dalam membawa pertumbuhan dan kemajuan ekonomi suatu negara. Pernyataan ini membantah pandangan, bahwa perkembangan ekonomi terutama tergantung dari proporsi pendapatan nasional yang digunakan untuk investasi fisik. Namun para ahli sepakat, bukannya jumlah investasi yang merupakan kunci perkembangan ekonomi itu, tetapi pemanfaatannya. Optimalisasi pemanfaatan ditentukan oleh pemilikan tenaga kerja yang berkemampuan dan berketerampilan tinggi yang mampu mendorong kecepatan perkembangan dan kemajuan ekonomi. Inilah yang merupakan sumbangan nyata yang diberikan pendidikan terhadap perkembangan ekonomi, sebab dari pendidikan dan lembaga risetlah dihasilkan tenaga kerja yang berkemampuan, berketerampilan, dan kemunculan ide dan teknik baru.

Penerapan MP3EI sebagai upaya mempercepat dan memperluas pertumbuhan ekonomi, memerlukan tenaga kerja yang berkemampuan dan berketerampilan menengah sampai dengan tinggi. Untuk menghasilkan tenaga kerja semacam itu diperlukan pendidikan yang bermutu, dan relevan dengan kebutuhan pembangunan. Dalam ekonomi yang semakin bergeser ke arah ekonomi berbasis pengetahuan, peran pendidikan tinggi sangat penting, antara lain untuk menghasilkan tenaga kerja yang memiliki keterampilan, unggul, dan produktif yang semakin mampu menerapkan ilmu pengetahuan dan teknologi yang dibutuhkan, dan untuk meningkatkan nilai tambah kegiatan ekonomi yang berkelanjutan.

Kemampuan dan keterampilan tenaga kerja merupakan hasil dari pendidikan dan pelatihan formal, baik diperoleh semasa menjalankan pendidikan di jenjang menengah dan tinggi, maupun diperoleh dari peraktek di tempat kerja. Di jenjang pendidikan tinggi khususnya, salah satu institusi pendidikan yang dapat memainkan peranan besar dalam membentuk dan mengembangkan kemampuan dan keterampilan itu adalah program pendidikan akademik, program pendidikan vokasi, serta program pendidikan profesi. Oleh karenanya tidak salah apabila UU No. 12/2012 Pasal 59 mengamanatkan pendirian Akademi Komunitas. Lebih lanjut Pasal 59 ayat (7) menyebutkan: Akademi Komunitas merupakan Perguruan Tinggi yang menyelenggarakan pendidikan vokasi setingkat diploma satu dan/atau diploma dua dalam satu atau beberapa cabang IImu Pengetahuan dan/atau Teknologi tertentu yang berbasis keunggulan lokal atau untuk memenuhi kebutuhan khusus. Tujuan didirikan Akademi Komunitas, antara lain: meningkatkan kompetensi yang sesuai dengan kebutuhan daerah maupun industri daerah; memperluas akses pendidikan tinggi atau APK perguruan tinggi; dan mendorong tumbuhnya usaha kecil dan menengah (UKM) di daerah sesuai dengan potensi ekonomi wilayah.

AK merupakan pendidikan formal setingkat perguruan tinggi, tetapi memiliki perbedaan dengan jenis perguruan tinggi lain. Kita telah lama mengenal perguruan tinggi Politeknik yang menyelenggarakan pendidikan vokasi dalam berbagai rumpun IImu Pengetahuan dan/atau Teknologi, dan jika memenuhi syarat, politeknik dapat menyelenggarakan pendidikan profesi. Demikian halnya telah lama dikenal perguruan tinggi setingkat Akademi yang menyelenggarakan pendidikan vokasi dalam satu atau beberapa cabang Ilmu Pengetahuan dan/atau Teknologi tertentu. Seperti telah dikatakan di atas, AK merupakan perguruan tinggi yang menyelenggarakan pendidikan vokasi setingkat diploma satu (D-1) dan/atau diploma dua (D-2) dalam satu atau beberapa cabang IImu Pengetahuan dan/ atau Teknologi tertentu yang berbasis keunggulan lokal atau untuk memenuhi kebutuhan khusus.

AK bukan merupakan barang baru. Sejumlah negara seperti Amerika, Australia, Inggris, dan lainlainnya, telah mendirikan perguruan tinggi sejenis AK dengan keunikannya masing-masing. Dalam konteks Indonesia, satu hal yang perlu digarisbawahi, AK merupakan wadah pendidikan tinggi yang didirikan untuk mengembangkan potensi lokal/daerah, sehingga dikatakan berbasis keunggulan lokal. Oleh karenanya, pengembangan program pendidikan AK sewajarnya di arahkan pada penyelarasan bidang dan program studi dengan potensi pengembangan ekonomi di setiap koridor ekonomi MP3El. Program akademik harus menjadi jejaring yang mengisi dan mengembangkan rantai nilai tambah dari setiap komoditas atau sektor yang dikembangkan di setiap koridor ekonomi. Universitas pusat riset dikembangkan secara nasional sebagai bagian penting dari pusat inovasi nasional. Pengembangan universitas pusat riset didasarkan pada prinsip integrasi, resource sharing, dan memanfaatkan teknologi informasi secara optimal.

Program pendidikan vokasi melalui AK didorong untuk menghasilkan lulusan yang terampil. Oleh karena itu di setiap kabupaten/kota dapat dikembangkan pendidikan tinggi berupa AK dengan bidangbidang studi yang sesuai dengan potensi di wilayah kabupaten/kota tersebut. Pengembangan AK yang menyelenggarakan program diploma 1 (D-1) dan/atau diploma 2 (D-2) diharapkan akan menghasilkan lulusan 
yang langsung dapat diserap oleh kegiatan ekonomi di pusat-pusat pertumbuhan ekonomi di setiap koridor ekonomi. Pengembangan AK dilakukan dengan secara bersama-sama antara pemerintah, dunia usaha, dan universitas sebagai pengelola AK. Mutu AK dikembangkan sesuai dengan potensi dan keunggulan setiap koridor ekonomi. Pendirian AK diharapkan dapat mendukung penerapan MP3El, tetapi juga memiliki tujuan lainnya. AK sebagai wadah pendidikan tinggi di jalur pendidikan vokasi atau kejuruan, juga ditujukan untuk menghindari pertambahan pengangguran usia muda, meningkatkan angka partisipasi kasar (APK) ke perguruan tinggi, serta berusaha meningkatkan dan menyediakan tenaga kerja yang berkualitas.

Sejak tahun 2012, dirintis pendirian 35 AK di beberapa kabupaten/kota, dan diharapkan nantinya di setiap kabupaten/kota secara bertahap membuka jenjang program setingkat D-1 dan D-2. Bagan di bawah menggambarkan alur hubungan antara MP3El dengan pendirian Akademi Komunitas di suatu daerah yang dapat dilihat pada gambar 2 .

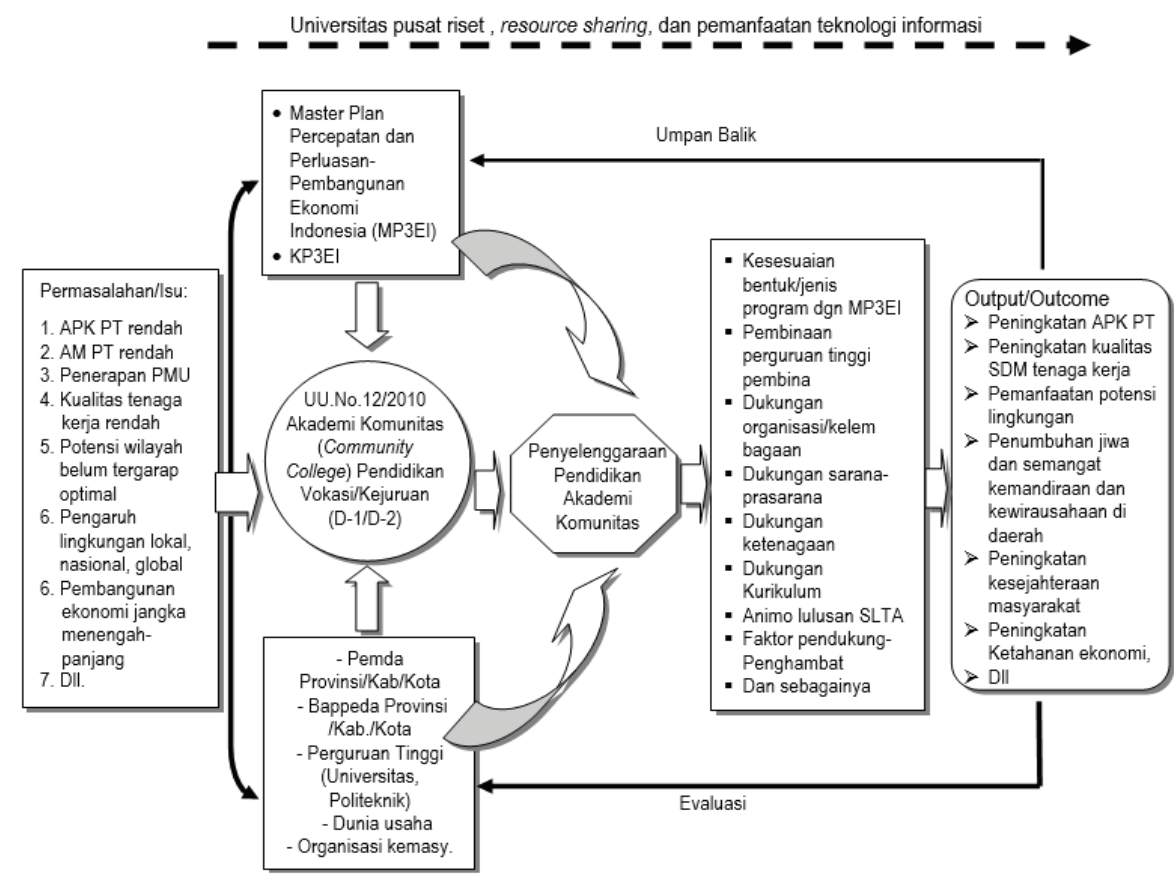

Gambar 2. Bagan penyelenggaraan dan hubungannya dengan MP3EI

Secara sederhana dalam bagan diperlihatkan, bahwa penyelenggaraan AK dilatarbelakangi oleh sejumlah isu atau permasalahan, antara lain masih rendahnya APK lulusan pendidikan menengah yang melanjutkan ke perguruan tinggi, kualitas pendidikan tenaga kerja yang sebagian besar masih memiliki latarbelakang pendidikan dasar dan menengah, penerapan penyelenggaraan pendidikan menengah universal untuk meningkatkan APK lulusan pendidikan dasar ke pendidikan menengah, dan sebagainya. Persoalan kian menjadi kompleks apabila pendirian AK dihubungkan dengan upaya pemenuhan kebutuhan menjawab tantangan global yang ditandai dengan iklim kompetitif antar bangsa yang semakin ketat dalam memperebutkan keterbatasan sumberdaya, serta perluasan dan percepatan pembangunan ekonomi Indonesia melalui konsep MP3EI.

Pendirian dan pengembangan program di AK selayaknya bukan hanya sekedar berfungsi menampung, memberi kesempatan, meningkatkan APK lulusan pendidikan menengah masuk PT, meningkatkan 74 Jurnal IImiah VISI P2TK PAUD NI - Vol. 9, No.1, Juni 2014 kualitas kemampuan dan keterampilan SDM tenaga kerja, tetapi juga merupakan upaya mendukung keberhasilan perluasan dan pertumbuhan ekonomi di setiap koridor ekonomi yang ditetapkan. Artinya, pendirian AK memerlukan keselarasan dengan penerapan konsep MP3EI sebagai upaya perluasan dan pembangunan ekonomi Indonesia. Jika AK diharapkan benar-benar mampu memberikan kontribusi terhadap percepatan dan perluasan pembangunan ekonomi wilayah/daerah, haruslah terdapat kesesuaian dan kesinergisan antara program studi yang dijalankan di AK dengan potensi ekonomi daerah. Di sisi lain penyelenggaraan AK perlu disosialisasikan secara meluas, didukung oleh akses pendidikan yang memadai, memperhatikan berbagai faktor pendukung dan penghambat pelaksanaan AK, dan yang lebih penting mengupayakan penyerapan lulusan di kawasan pengembangan ekonomi MP3El. AK haruslah sedini mungkin menghindarkan dan mencegah munculnya pengangguran terdidik, disebabkan oleh ketidaksesuaian lulusannya dengan kebutuhan di sekitarnya. Penyelenggaraan AK harus 
benar-benar dirasakan manfaatnya oleh masyarakat sekitar, meningkatkan kesejahteraan, menumbuhkan jiwa dan semangat kewirausahaan, dan akhirnya mem- bentuk kondisi ketahanan ekonomi yang tangguh bagi di daerah di sekitarnya.

\section{PEMBAHASAN}

Di bawah ini selanjutnya akan dikemukakan hasil kajian terhadap 12 Akademi Komunitas terkait dengan analisis tentang kesesuaian program studi yang dijalankan, ketepatan lokasi, dan konflik hubungan yang berlangsung antara perguruan tinggi (politeknik) pembina dengan AK.

\section{Kesesuaian Program Studi}

Amanat UU No. 12/2012 pasal 59, ditindaklanjuti oleh pihak kementerian melalui penerbitan Kepmendikbud No. 161/P/2012 tanggal 9 Agustus 2012, dengan mendirikan AK dengan perincian 20 AK dibiayai oleh
APBN dan 15 AK dibiayai melalui APBN-Perubahan. Dalam tabel 2 di bawah dikemukakan pendirian AK yang tertuang dalam Kepmendikbud yang telah dikaitkan pula dengan koridor ekonomi MP3El, dengan tujuan untuk mengetahui seberapa jauh kesesuaian antara program studi yang diselenggarakan oleh AK dengan pengembangan potensi ekonomi yang tercakup dalam MP3EI. Di samping itu, dipastikan bahwa jumlah tersebut akan semakin bertambah selaras dengan banyaknya daerah yang berminat untuk mendirikan Akademi Komunitas.

Tabel 2. Persebaran Pendirian AK

\begin{tabular}{|c|c|c|c|c|}
\hline Koridor & Potensi Pengembangan & $\begin{array}{c}\text { Perguruan Tinggi } \\
\text { Penyelenggara }\end{array}$ & Kab. Lok. AK & Program Studi \\
\hline \multirow[t]{2}{*}{ Sumatera } & \multirow[b]{2}{*}{$\begin{array}{l}\text { Kegiatan ekonomi utama } \\
\text { antara lain: perkebunan ke- } \\
\text { lapa sawit, perkebunan karet, } \\
\text { tambang batubara, perkapa- } \\
\text { lan, besi baja, dan Kawasan } \\
\text { Strategis Nasional (KSN) Selat } \\
\text { Sunda. }\end{array}$} & \multirow[t]{2}{*}{ Politeknik Negeri Lampung } & \multirow[t]{2}{*}{ 1. Kab. Muko-Muko } & - Budi daya pertanian \\
\hline & & & & - Budi daya Perikanan \\
\hline & \multirow{22}{*}{$\begin{array}{l}\text { Di samping itu terdapat be- } \\
\text { berapa kegiatan yang dinilai } \\
\text { mempunyai potensi pengem- } \\
\text { bangan, seperti Pertanian } \\
\text { Pangan, Pariwisata, Migas, } \\
\text { Perkayuan, dan Perikanan. } \\
\text { Adapun untuk mengamankan } \\
\text { ketersediaan produksi pangan } \\
\text { dilakukan pengembangan } \\
\text { lumbung pangan di Aceh }\end{array}$} & & \multirow{3}{*}{$\begin{array}{l}\text { 2. Kab.Lampung Ten- } \\
\text { gah*) }^{*}\end{array}$} & - T. Komp \& Jaringan \\
\hline & & & & $\begin{array}{l}\text { - Manajemen Informa- } \\
\text { tika }\end{array}$ \\
\hline & & & & - Multimedia \\
\hline & & & \multirow[t]{3}{*}{ 3. Kab. Rejang Lebong } & $\begin{array}{l}\text { - Agribisnis Hasil Per- } \\
\text { tanian }\end{array}$ \\
\hline & & & & - Agribisnis Perikanan \\
\hline & & & & - Agribisnis Peternakan \\
\hline & & & \multirow[t]{3}{*}{ 4. Kab. Cianjur*) } & $\begin{array}{l}\text { - Tek. Pengol Hsl Per- } \\
\text { tanian }\end{array}$ \\
\hline & & & & - Budi daya Perairan \\
\hline & & & & $\begin{array}{l}\text { - Tanam Pangan \& } \\
\text { Holtikultura }\end{array}$ \\
\hline & & \multirow{3}{*}{$\begin{array}{l}\text { Politeknik Negeri Lhokseu- } \\
\text { mawe }\end{array}$} & \multirow[t]{3}{*}{ 5. Kab. Aceh Barat } & - Teknik Mesin Industri \\
\hline & & & & - Teknik Elektro \\
\hline & & & & - Teknik Sipil \\
\hline & & \multirow[t]{3}{*}{ Politeknik Negeri Padang } & \multirow[t]{3}{*}{ 6. Kab. Tanah Datar } & - Teknik Informatika \\
\hline & & & & - Teknik Sipil \\
\hline & & & & - Teknik Mesin \\
\hline & & \multirow[t]{5}{*}{ Politeknik Negeri Sriwijaya } & \multirow[t]{3}{*}{ 7. Kota Prabumulih*) } & - Teknik Komputer \\
\hline & & & & - Akutansi \\
\hline & & & & - Adm. Perkantoran \\
\hline & & & 8. Kota Pangkalpinang & - Teknik Informatika \\
\hline & & & 9. Kab. Pagar Alam & $\begin{array}{l}\text { - Informasi \& Telekomu- } \\
\text { nikasi }\end{array}$ \\
\hline & & \multirow[t]{2}{*}{ Politeknik Negeri Medan } & \multirow[t]{2}{*}{ 10. Kab. Deli Serdang } & - Teknik Permesinan \\
\hline & & & & - Teknik Komputer \\
\hline
\end{tabular}




\begin{tabular}{|c|c|c|c|c|}
\hline Koridor & Potensi Pengembangan & $\begin{array}{c}\text { Perguruan Tinggi } \\
\text { Penyelenggara }\end{array}$ & Kab. Lok. AK & Program Studi \\
\hline \multirow[t]{22}{*}{ Jawa } & \multirow{22}{*}{$\begin{array}{l}\text { Kegiatan ekonomi utama } \\
\text { makanan-minuman, tekstil, } \\
\text { dan peralatan transportasi. } \\
\text { Selain itu terdapat pula aspirasi } \\
\text { untuk mengembangkan kegiatan } \\
\text { ekonomi utama perkapalan, } \\
\text { telematika, dan alat utama sistem } \\
\text { senjata (alutsista). Percepatan dan } \\
\text { perluasan perekonomian di Ko- } \\
\text { ridor Ekonomi Jawa diharapkan } \\
\text { dapat memperkuat posisi Koridor } \\
\text { Ekonomi Jawa sebagai "Pusat } \\
\text { Pengembangan Industri dan } \\
\text { Jasa Nasional" dan memberikan } \\
\text { efek positif bagi pengembangan } \\
\text { Koridor lainnya. }\end{array}$} & \multirow{12}{*}{$\begin{array}{l}\text { Politeknik Elektronika Negeri } \\
\text { Surabaya }\end{array}$} & \multirow[t]{2}{*}{ 11. Kab. Ponorogo } & - Teknik Informatika \\
\hline & & & & - Mekatronika \\
\hline & & & \multirow[t]{3}{*}{ 12. Kab. Pacitan*) } & - Animasi \\
\hline & & & & - Multimedia \\
\hline & & & & - Teknik Informasi \\
\hline & & & \multirow[t]{2}{*}{ 13. Kab. Sumenep } & - Teknik Informatika \\
\hline & & & & - Teknik Multimedia \\
\hline & & & \multirow[t]{2}{*}{ 14. Kab. Lamongan } & - Teknik Informatika \\
\hline & & & & - Multimedia \\
\hline & & & \multirow[t]{3}{*}{ 15. Kab. Temanggung } & - Budi daya Kelapa Sawit \\
\hline & & & & $\begin{array}{l}\text { - Teknik Pengol Hsl } \\
\text { Pertanian }\end{array}$ \\
\hline & & & & - M. Informatika \\
\hline & & \multirow[t]{10}{*}{ Politeknik Negeri Jember } & \multirow[t]{2}{*}{ 16. Kab. Situbondo } & - Teknik Informasi \\
\hline & & & & - Industri Pangan \\
\hline & & & \multirow[t]{3}{*}{ 17. Kab. Sidoarjo } & $\begin{array}{l}\text { - Boga Pengol Hsl Peri- } \\
\text { kanan }\end{array}$ \\
\hline & & & & - Teknik Informatika \\
\hline & & & & - Multimedia \\
\hline & & & \multirow[t]{2}{*}{ 18. Kab. Nganjuk } & - Pengol. Hsl Pertanian \\
\hline & & & & - Teknik Informatika \\
\hline & & & \multirow[t]{3}{*}{ 19. Kota Blitar*) } & - Teknologi Informasi \\
\hline & & & & - Multimedia \\
\hline & & & & - Adm. Perkantoran \\
\hline & & & \multirow[t]{3}{*}{ 20. Kota Bojonegoro } & - Komputer Akuntansi \\
\hline & & & & - Teknik Informatika \\
\hline & & & & - Teknik Otomotif \\
\hline & & \multirow[t]{3}{*}{ Politeknik Negeri Malang } & \multirow[t]{3}{*}{ 21. Kab. Jepara } & - Otomotif \\
\hline & & & & $\begin{array}{l}\text { - Tek. Inform \& Teleko- } \\
\text { munikasi }\end{array}$ \\
\hline & & & & - Teknik Informatika \\
\hline & & Politeknik Negeri Semarang & 22. Kab. Tuban & - Teknik Elektronika \\
\hline & & \multirow[t]{4}{*}{ Politeknik Negeri Bandung } & \multirow[t]{4}{*}{ 23. Kab. Karawang*) } & - Tekn Pemeliharaan Mesin \\
\hline & & & & $\begin{array}{l}\text { - Tekn Perancang Mekanis } \\
\text { Umum }\end{array}$ \\
\hline & & & & - Teknik Mekatronika \\
\hline & & & & - Perhotelan \\
\hline \multirow[t]{8}{*}{$\begin{array}{l}\text { Bali-Nusa } \\
\text { Tenggara }\end{array}$} & \multirow{8}{*}{$\begin{array}{l}\text { Pengembangan Koridor Ekonomi } \\
\text { Bali - Nusa Tenggara difokus- } \\
\text { kan pada } 9 \text { destinasi Pariwisata } \\
\text { Nasional. Dalam mengembang- } \\
\text { kan pendukung ketahanan pangan } \\
\text { nasional, di koridor Bali - Nusa } \\
\text { Tenggara dikembangkan kegiatan } \\
\text { ekonomi utama perikanan, } \\
\text { produk kelautan (seperti: rumput } \\
\text { laut dan garam). Di samping itu } \\
\text { dikembangkan kegiatan ekonomi } \\
\text { utama peternakan Sapi Bali. }\end{array}$} & \multirow[t]{4}{*}{ Politeknik Negeri Bali } & \multirow[t]{3}{*}{ 24. Kota Mataram*) } & - Agrowisata \\
\hline & & & & - Usaha Jasa Pariwisata \\
\hline & & & & - Hotel dan Restoran \\
\hline & & & 25. Kab. Gianyar*) & - Perhotelan \\
\hline & & \multirow[t]{4}{*}{ Politeknik Negeri Kupang } & 26. Kab. Sumba Timur & - „......................................... \\
\hline & & & \multirow[t]{3}{*}{ 27. Kab. Sumbawa } & - Budi daya Pertanian \\
\hline & & & & $\begin{array}{l}\text { - Teknologi Hasil Peri- } \\
\text { kanan }\end{array}$ \\
\hline & & & & - Peternakan \\
\hline
\end{tabular}




\begin{tabular}{|c|c|c|c|c|}
\hline Koridor & Potensi Pengembangan & $\begin{array}{c}\text { Perguruan Tinggi } \\
\text { Penyelenggara }\end{array}$ & Kab. Lok. AK & Program Studi \\
\hline \multirow[t]{6}{*}{ Kalimantan } & \multirow{6}{*}{$\begin{array}{l}\text { Koridor ini ditetapkan sebagai } \\
\text { pilar energi nasional, terutama } \\
\text { mengingat kandungan potensi } \\
\text { sumberdaya migas dan batubara } \\
\text { yang ada di wilayah ini. Selain } \\
\text { itu, koridor ekonomi Kalimantan } \\
\text { juga menyimpan kekayaan alam } \\
\text { yang berpotensi untuk dikem- } \\
\text { bangkan, seperti besi baja, bauk- } \\
\text { sit, kelapa sawit, dan perkayuan }\end{array}$} & \multirow[t]{2}{*}{ Politeknik Negeri Pontianak } & \multirow[t]{2}{*}{ 28. Kota Singkawang*) } & - Pengol Hsl Pertanian \\
\hline & & & & - Teknologi Informatika \\
\hline & & \multirow[t]{2}{*}{ Politeknik Negeri Samarinda } & \multirow[t]{2}{*}{ 29. Kota Bontang } & - Kimia Analis \\
\hline & & & & - Teknik Alat Berat \\
\hline & & \multirow[t]{2}{*}{ Politeknik Negeri Banjarmasin } & \multirow{2}{*}{$\begin{array}{l}\text { 30. Kab Kotawaringin } \\
\text { Timur }\end{array}$} & - Teknik Komp \& Jaringan \\
\hline & & & & $\begin{array}{l}\text { - Teknik Mekanik Oto- } \\
\text { motif }\end{array}$ \\
\hline \multirow[t]{5}{*}{ Sulawesi } & \multirow{5}{*}{$\begin{array}{l}\text { Tema pembangunan Koridor } \\
\text { Ekonomi Sulawesi adalah sebagai } \\
\text { Pusat Produksi dan Pengola- } \\
\text { han Hasil Pertanian (beras dan } \\
\text { jagung), Perkebunan (kakao), } \\
\text { Perikanan, Minyak dan gas bumi, } \\
\text { dan Pertambangan (nikel). . }\end{array}$} & \multirow[t]{2}{*}{ Politeknik Negeri Ujung Pandang } & \multirow[t]{2}{*}{ 31. Kab. Buru } & - Perikanan \\
\hline & & & & - Agro teknologi \\
\hline & & \multirow[t]{3}{*}{$\begin{array}{l}\text { Politeknik Pertanian Negeri } \\
\text { Pangkajene Kepulauan, }\end{array}$} & \multirow[t]{2}{*}{ 32. Kab. Nagekeo } & $\begin{array}{l}\text { - Tek Prod \& Pengol } \\
\text { Garam }\end{array}$ \\
\hline & & & & - Manajemen Perusahaan \\
\hline & & & 33. Kab. Kolaka*) & - Budi daya Perikanan \\
\hline \multirow{4}{*}{$\begin{array}{l}\text { Papua-Kep. } \\
\text { Maluku }\end{array}$} & \multirow{4}{*}{$\begin{array}{l}\text { Strategi pembangunan ekonomi } \\
\text { Koridor Ekonomi Papua dan } \\
\text { Kepulauan Maluku difokuskan } \\
\text { pada } 5 \text { kegiatan Ekonomi utama, } \\
\text { yaitu Pertanian Pangan - MIFEE } \\
\text { (Merauke Integrated Food \& } \\
\text { Energy Estate), Tembaga, Nikel, } \\
\text { Migas, dan Perikanan. }\end{array}$} & \multirow[t]{4}{*}{ Politeknik Negeri Ujung Pandang } & \multirow[t]{2}{*}{ 34. Kab. Manokwari } & - Teknik Automotif \\
\hline & & & & - TIK \\
\hline & & & \multirow[t]{2}{*}{ 35. Kab. Keerom } & - Teknik Informatika \\
\hline & & & & - Teknik Otomotif \\
\hline
\end{tabular}

* Sumber: Diolah dari Bappenas, Thn 2012, dan Direktorat Kelembagaan dan Kerjasama, Direktorat Jenderal Pendidikan Tinggi Kementerian Pendidikan dan Kebudayaan, Tahun 2012.

*) Sampel Penelitian

Hasil penelitian ini mendapatkan, bahwa upaya pendirian AK ditengarai masih menghadapi permasalahan. Daerah yang ditunjuk sebagai tempat menyelenggarakan AK kerapkali belum cukup siap untuk menyelenggarakan pendidikan vokasi AK, baik dari sisi wadah, pengorganisasian kerja, ketersediaan sarana-prasarana pendukung, ketenagaan, kurikulum, dan sebagainya. Meski demikian pihak pemerintah daerah (Kabupaten/Kota) menanggapi positif pendirian AK di daerahnya, dan membentuk kelompok kerja (Panitya Persiapan Pendirian AK) untuk merealisasikan tujuan tersebut. Dari pihak Kemdikbud pun menentukan agar pendirian AK memperoleh pembinaan dari politeknik tertentu, dan untuk sementara disebut dengan Pendidikan Di luar Domisili (PDD). Pembinaan akan dihentikan apabila PDD dianggap telah mampu mandiri, menjamin keberlanjutannya, dan benar-benar dinilai telah dapat dihandalkan sebagai perguruan tinggi penyelenggara pendidikan tinggi vokasi yang dinamakan Akademi Komunitas ini.

Namun hasil penelitian pula menunjukkan, bahwa penentuan dan penyelenggaraan bentuk/jenis program studi di PDD sebagian besar tidak berbeda jauh dengan program studi yang ada di politeknik pembina. Pertanyaannya, apakah program studi yang diselenggarakan di PDD selaras dengan pengembangan potensi ekonomi daerah sejalan dengan penerapan konsep MP3EI?
Harus diakui tidaklah mudah untuk mengetahui, sejauhmana terdapat keselarasan antara program studi yang diselenggarakan oleh AK dengan konsep MP3EI yang bertumpu pada pengembangan potensi ekonomi wilayah. Keterkaitan dan keselarasan itu bisa bersifat langsung, tetapi juga tidak langsung. Sulit disimpulkan, apakah program studi teknik mesin industri, teknik elektro, dan teknik sipil yang diselenggarakan oleh AK Kab. Aceh Barat, benar-benar telah selaras dengan upaya menjadikan daerah ini sebagai lumbung pangan? Demikian halnya, sejauhmana kesesuaian antara pengembangan ekonomi di koridor ekonomi Papua-Kepulauan Maluku yang menekankan pada kegiatan ekonomi Pertanian Pangan, Tembaga, Nikel, Migas, dan Perikanan dengan program studi Teknik Otomotif dan Teknik Informatika yang diselenggarakan AK di Kabupaten Manokwari dan Kroom? Apakah program studi Teknik Komputer \& Jaringan, Manajemen Informatika, dan Multimedia yang diselenggarakan oleh AK Kabupaten Lampung Tengah sesuai dengan potensi dan kebutuhan daerah? Penilaian terhadap penentuan program studi AK itu bisa bersifat subyektif dan mengundang perdebatan, namun kesan yang ada bahwa program studi yang diselenggarakan oleh AK cenderung kurang sesuai dengan potensi ekonomi daerah yang akan dikembangkan.

Indikasi tidak atau kurang sesuainya program studi dengan potensi ekonomi daerah di sekitarnya, 
diperkuat dengan fenomena yang terjadi di lapangan. Sejumlah pengelola AK di daerah mengemukakan, bahwa program studi yang diselenggarakan sebenarnya kurang sesuai dengan potensi ekonomi daerah di sekitarnya. Namun harus diterima, karena sudah ditentukan oleh pihak Direktorat Jenderal Pendidikan Tinggi - Kementerian Pendidikan dan Kebudayaan. Pengajuan atau usulan program studi dari pengelola AK yang diperoleh dari tindakan pemetaan potensi dan kebutuhan daerah, kerapkali tidak selaras dengan yang dikeluarkan oleh pihak Ditjen Dikti. Kasus di salah satu daerah di Kabupaten Lampung Tengah misalnya, menurut pengelola AK di daerah tersebut telah mengusulkan sebanyak 3 (tiga) program studi yang terkait dengan pengembangan sektor perkebunan dan pertanian yang dinilai sesuai dengan potensi ekonomi wilayah. Nyatanya Ditjen Dikti memutuskan lain, dengan menentukan penyelenggaraan program studi yang sama sekali berbeda. Ketidak atau kekurang sesuaian itu tampak pula terhadap program studi Teknik Pengelasan (fabrikasi) yang diselenggarakan di salah satu daerah di wilayah Provinsi Sumatera Selatan, padahal di daerah tidak terdapat bangunan pabrik dan dinilai kurang membutuhkan lulusan prodi tersebut. Contoh lain adalah AK yang menyelenggarakan prodi teknik komputer dan multimedia di salah satu kabupaten di Provinsi Jawa Timur yang tidak berbeda dengan prodi yang ada di politeknik pembina yang berdomisili di Surabaya, apakah memiliki kesesuaian dengan potensi daerah di bidang kepariwisataan dan pertambangan khususnya?

Dari pihak Ditjen Dikti sendiri dalam suatu seminar yang diselenggarakan oleh salah satu bidang di lingkungan Puslitjak, Balitbang-Kemdikbud tahun 2014, cenderung mengakui seringnya terjadi ketidaksesuaian antara prodi yang diselenggarakan oleh AK di sejumlah tempat dengan potensi daerah di sekitarnya. Alasan yang dikemukakan, penentuan dan penyelenggaraan prodi asal jalan dulu, bersifat sementara dan bisa diubah setelah AK mengalami penguatan kelembagaan. Dalam konteks terjadinya perubahan itulah AK dapat menyesuaikan prodinya dengan potensi dan kebutuhan daerah sekitarnya. Alasan itu memang mengherankan, bukankah pendirian AK diharapkan memiliki perbedaan hakiki dengan pendidikan vokasi lain, terutama keselarasannya dengan kebutuhan dan potensi setempat guna mendukung pertumbuhan ekonomi daerah.

\section{Ketepatan Lokasi AK}

Fenomena lain yang diperoleh dari hasil penelitian adalah kekurangtepatan penunjukkan lokasi atau tempat penyelenggaraan AK. Pendirian AK di suatu daerah dihadapkan dengan keberadaan jumlah perguruan tinggi yang telah relatif banyak. Kasus penyelenggaran AK di salah satu kota di Provinsi Jawa Barat misalnya, dihadapkan dengan keberadaan sebanyak 16 perguruan tinggi swasta di wilayah ini yang telah menyelenggarakan pendidikan tinggi mulai dari bentuk program diploma-3 (D-3) sampai dengan tingkat doktoral. Daerah ini pun relatif dekat dengan ibukota provinsi yang memiliki sejumlah perguruan tinggi negeri dan swasta lainnya. Pihak Ditjen Dikti menyetujui untuk didirikan AK di daerah ini yang diselenggarakan oleh lembaga pemerintah tertentu dengan mengkategorikannya sebagai tipe 'penugasan'. Menurut hemat kami, apabila tidak disikapi serius diduga penyelenggaraan AK yang bersangkutan akan menghadapi permasalahan di masa datang yang dapat merugikan keberlangsungan pendidikan mahasiswanya.

Kasus lain mengenai kekurangtepatan dan memerlukan perhatiannya adalah pendirian AK yang penempatannya di daerah yang telah memiliki lembaga pendidikan tinggi dengan program studi serupa dengan yang diselenggarakan AK. Salah satu kasus adalah pendirian AK di Provinsi Nusa Tenggara Barat yang menyelenggarakan prodi kepariwisataan dengan politeknik pembina berada di Provinsi Bali. Muncul pertanyaan, apakah pendirian AK perlu dilakukan, padahal di daerah itu sudah terdapat SMK Pariwisata dan Akademi Pariwisata program diploma-3 (D-3) yang sudah relatif mapan. Lembaga pendidikan ini telah memiliki dan didukung oleh fasilitas belajar yang memadai, berbeda halnya dengan AK yang masih menumpang di salah satu sekolah dan belum ditopang oleh fasilitas belajar yang memadai. Diprediksi lulusan AK nantinya harus bersaing dengan lulusan SMK dan pemegang ijazah diploma-3 dalam memperebutkan peluang kerja, padahal lulusan yang disebut terakhir itu cenderung lebih memiliki kemampuan dan keterampilan yang dibutuhkan oleh dunia kerja di sekitarnya, bahkan lulusannya diminati oleh badan-badan usaha di bidang kepariwisataan yang berada di negara jiran dan lainnya.

\section{Konflik Hubungan}

Di daerah yang ditunjuk oleh Kepmendikbud No. 161/P/2012 sebagai lokasi AK, telah membentuk panitia/tim kerja (baca: pengelola) untuk merencanakan dan menyiapkan pendirian AK. Sebagai bagian dari proses penyiapan itu, pihak Ditjen Dikti telah pula menunjuk sejumlah perguruan tinggi politeknik negeri yang bertindak sebagai pembina bagi AK. Untuk sementara waktu rintisan AK disebut dengan istilah Pendidikan Di luar Domisili (PDD) yang berada dalam pembinaan politeknik tertentu (lihat: tabel 2 di atas). 
Semasih menggunakan nama PDD, peserta didik yang menjalankan perkuliahan di AK tercatat sebagai mahasiswa dari politeknik pembina.

Komitmen kementerian pendidikan dan kebudayaan terhadap pendirian AK, salah satunya diwujudkan melalui pengalokasian dana yang cukup besar untuk kepentingan tersebut. Alokasi dana yang disediakan disalurkan melalui politeknik yang ditentukan/ ditunjuk, karena rintisan AK dianggap belum memiliki wujud yang jelas dan belum menjadi wadah berbadan hukum kuat dan mandiri. Politeknik Negeri Lampung misalnya, memperoleh alokasi dana sebesar Rp. 22 milyar untuk penyiapan pendirian dan pembinaan AK di kota Cianjur, Kab. Lampung Tengah, Kab. Rejang Lebong, dan Kab. Muko-Muko - Bengkulu. Politeknik Elektronika Negeri Surabaya memperoleh alokasi dana sebesar Rp. 80 milyar untuk penyiapan pendirian dan pembinaan AK di Kab. Pacitan, Kab. Ponorogo, Kab. Lamongan, dan Kab. Sumenep - Madura. Politeknik Manufaktur Negeri Bandung memperoleh alokasi dana sebesar Rp. 22 milyar untuk penyiapan pendirian dan pembinaan AK Kab. Karawang. Politeknik Negeri Bali memperoleh alokasi dana sebesar Rp. 20 milyar untuk penyiapan pendirian dan pembinaan AK Kab Gianyar dan Kota Mataram - Nusa Tenggara Barat. Dan masih banyak politeknik lainnya yang memperoleh alokasi dana pembinaan dan penyiapan pendirian AK, yang tidak disebutkan satu-persatu di sini.

Namun penelitian ini mendapatkan, tidak jarang alokasi dana yang diberikan untuk penyiapan pendirian AK memunculkan ketidakharmonisan hubungan antara pihak politeknik pembina dengan AK Binaan terkait dengan pengelolaan dana. Pihak politeknik dianggap kurang berlaku transparans, dan bahkan dianggap lebih menguntungkan mereka. Kasus di salah satu AK misalnya, dari sejumlah 36 orang yang terkategori pengelola PDD, sebanyak 26 orang berasal dari politeknik pembina, sebaliknya hanya 10 orang yang berasal dari daerah tempat AK didirikan. Konsekuensinya, pemberian honor yang bersumber dari pos pengelola PDD, sebagian besar tertuju pada mereka yang berasal dari politeknik pembina. Salah seorang pengelola AK di daerah mengemukan, "Kami tidak tahu kerja orangorang di politeknik pembina (sering disebut dengan: poltek) yang tercantum dalam daftar, padahal memperoleh honorarium. Kami mengurus dan mengelola AK yang setiap hari harus hadir, hanya memperoleh honor Rp. 300 ribu - Rp. 450 ribu,- per bulannya. Hanya karena komitmen saja yang membuat kami tetap bertahan, dengan harapan mengalami perubahan jika AK telah mandiri. Anggaran untuk penyiapan dan pendirian AK di daerah ini tercatat sebesar Rp. 5 milyar,-, tapi sejauh ini kami baru menerima dari poltek untuk keperluan membayar honorarium pengurus $\mathrm{Rp}$. 20 juta,-, serta pembayaran honor tenaga pengajar sebesar Rp. 60 juta,- untuk mengajar selama satu semester."

Kasus seperti di atas dialami pula oleh pengelola AK di daerah lain. Salah satu pengelola AK yang berada di Provinsi Jawa Timur mengemukakan: "Kami tidak mengetahui status anggaran yang dititipkan melalui politeknik pembina. Sejauhmana kewenangan kami dalam penggunaannya, karena segala sesuatunya amat tergantung dari politeknik pembina. Situasi kami hanya sekedar menunggu, tanpa kemampuan berbuat apa-apa terhadap dana yang ada. Dari alokasi anggaran sekitar Rp. 20 milyar,- untuk keperluan penyiapan dan pendirian AK, kami baru memperoleh pembayaran honor beberapa bulan." Anehnya, menurut catatan, pihak politeknik telah mengeluarkan biaya pengelolaan AK di daerah ini sebanyak Rp. 7,8 milyar tahun 2012, dan sekitar Rp. 7 milyar tahun 2013. Padahal pada tahun 2012, SK Permendikbud tentang penunjukkan pendirian AK di daerah tersebut baru dikeluarkan bulan Agustus?

Kasus lain berlangsung terhadap AK di daerah lain yang ditandai dengan tindakan pemecatan terhadap pengelola lama. Alasannya, pengelola lama telah melakukan penyimpangan, baik terhadap pembayaran SPP mahasiswa, sarana-prasarana yang disediakan oleh politeknik pembina yang dinilai sebagai aset negara, dan honor pengelola dan tenaga pengajar. Sampai penelitian ini dilaksanakan, konflik masih berlangsung antara pengelola lama dengan politeknik pembina yang didukung oleh pengelola baru. Menurut keterangan pengelola lama, AK memang saat itu belum memiliki dana operasional, tetapi penggunaan dana dari sumber SPP itu tidak akan terjadi jika tidak mendapat ijin dari politeknik pembina. Menurut pihak politeknik, penggunaan itu akan mendapat penggantian saat dana dari pusat cair. Dalam perkembangan selanjutnya, pihak politeknik pembina maupun pengelola baru cenderung menuduh pengelola lama telah melakukan penyimpangan dana SPP mahasiswa.

Tudingan lain yang di arahkan ke pengelola lama adalah penilepan honor tenaga pengajar (dosen) AK untuk semester 1 tahun 2013. Tudingan itu diperkuat dengan daftar penerimaan honor tenaga pengajar yang tidak dikirimkan kembali oleh pengelola lama ke politeknik pembina. Sampai akhir oktober 2013 lalu, memang daftar itu masih ditahan oleh pengelola lama. Dalih yang dikemukakan, karena pengelola lama telah relatif banyak menalangi dari kocek sendiri untuk keperluan operasional AK, seperti pemasangan listrik 
sebesar Rp. 9 juta,-, pembuatan teralis jendela sebesar Rp. 6 juta,-, dan lain-lainnya. Pengeluaran dana talangan tersebut dilakukan atas janji poltek yang akan memberikan penggantian apabila anggaran dari pusat cair. Namun penggantian itu tidak kunjung turun, bahkan berakibat terjadinya tindak pemecatan dan peralihan pengelolaan PDD/AK ke pengelola baru. Pihak politeknik pembina cenderung bersikap lepas tangan dan tidak mau tahu-menahu terhadap pengeluaran dana talangan itu. Kami sendiri diperlihatkan daftar penerima honorarium yang memang sebagian besar telah menerima honor mengajar dan membubuhkan tandatangannya, sebaliknya hanya terdapat beberapa orang yang masih belum menandatangani. Menurut pengelola lama, mereka yang belum menerima dan menandatangani daftar honorarium merupakan 'orangnya' pengelola baru, yang sengaja tidak mau menerima honor pembayaran dengan maksud menyudutkan pengelola lama.

Tindakan pemecatan nyatanya juga telah menjurus pada situasi fitnah, dengan tuduhan pengelola lama telah melakukan penggelapan terhadap barangbarang yang dikirimkan politeknik pembina untuk menunjang pendidikan di PDD/AK. Tuduhan yang dilontarkan, pengelola lama tidak mau menyerahkan asset yang dibeli oleh politeknik pembina yang bersumber dari uang negara. Lalu, mengapa pihak politeknik pembina dan pengelola baru mengembangkan isu telah terjadi pengangkangan hak terhadap asset negara oleh pengelola lama? Menurut pengelola lama, bahwa hal itu sengaja dihembuskan agar dapat digunakan sebagai salah satu alasan untuk melakukan pemecatan. Tindakan ini dilakukan karena pengelola lama dianggap kurang bersikap kooperatif, salah satunya tercermin dari penolakan mereka untuk membubuhkan tanda tangan di daftar penerimaan barang yang dikirimkan oleh politeknik pembina. Penolakan itu disebabkan oleh banyaknya jenis barang yang tercantum dalam daftar pengiriman tetapi tidak ada dalam pengiriman barang. Menurut pengamatan kami, memang hampir sebagian besar jenis dan nama barang yang ditulis dalam daftar tidak dikirim oleh perusahaan rekanan politeknik pembina. Bukan itu semata, dari jenis barang yang ada pun telah mengalami mark up berlipat-lipat kali dari harga sebenarnya. Pembuatan satu buah kerambah ikan misalnya, diperkirakan memiliki taksiran harga berkisar antara Rp. 30 juta,-- Rp. 40 juta,--, tetapi tertulis dipertanggungjawabkan sebanyak 4 buah @ Rp. 140 juta,-. Bahkan pengiriman ratusan bangku belajar mahasiswa, menurut perkiraan kami, hanya seharga kurang lebih Rp. 50 ribu,-- per buahnya, namun tertulis dipertanggungjawabkan dengan harga satuan Rp. 630 ribu dan Rp. 580 ribu. Masih banyak contoh lainnya jenis barang yang mengalami mark up dari harga sebenarnya tersebut.

Menurut pihak pengelola lama, mereka bukan bermaksud menahan ataupun menggelapkan barangbarang tersebut. Pengelola lama menginginkan, apabila terjadi penyerahan barang ke pengelola baru, agar turut dihadiri dan disaksikan oleh pihak politeknik pembina, aparatur pemerintah daerah yang terkait, dan aparat kepolisian setempat. Kehadiran pihak politeknik pembina amat penting untuk mengklarifikasi jenis barang yang dikirim, serta mencegah munculnya tuduhan bahwa pengelola lama telah menghilangkan jenis barang tertentu yang sebenarnya tidak pernah diterimanya. Sejauh ini politeknik pembina tidak menanggapi permintaan pihak pengelola lama, dan melulu hanya memerintahkan secara lisan agar pengelola lama menyerahkan barang-barang itu ke pengelola baru.

\section{PENUTUP}

\section{Kesimpulan}

Kementerian Pendidikan dan Kebudayaan memiliki komitmen tinggi untuk mendukung pendirian Akademi Komunitas Negeri di daerah. Pendirian AK diharapkan dapat memberikan kontribusi dalam meningkatkan dan membentuk kualitas SDM di daerah, dan selaras dengan pengembangan potensi ekonomi wilayah. Untuk itu diharapkan penentuan program studi di AK (yang sementara masih berstatus Pendidikan Di luar Domisili (PDD) dan berada dalam binaan politeknik tertentu) memiliki keselarasan terhadap pengembangan potensi ekonomi dari setiap koridor ekonomi yang dikembangkan.
Namun dari kajian di lapangan dihasilkan, bahwa penyelenggaraan PDD/AK di sejumlah daerah terkesan kurang selaras dengan potensi ekonomi di sekitarnya. Usulan untuk menyelenggarakan program studi tertentu yang dikaitkan dengan upaya pemetaan kebutuhan daerah, ternyata kurang ditanggapi oleh pihak Ditjen Dikti dengan menentukan program studi PDD/AK yang sama sekali berbeda. Bahkan di beberapa daerah memunculkan pertanyaan, apakah daerah yang bersangkutan benar-benar memerlukan adanya AK atau sebaliknya? Hal itu karena daerah tempat PDD/AK didirikan telah memiliki perguruan tinggi dengan jumlah yang memadai, dekat dengan 
daerah lain yang memiliki perguruan tinggi negeri dan swasta dengan jumlah memadai pula, atau di daerah yang bersangkutan telah ada sejak lama Sekolah Menengah Kejuruan dan Akademi/Politeknik program diploma - 3 (D-3) dengan program studi yang sama dengan yang diselenggarakan oleh PDD/AK.

Dari kajian lapangan juga dihasilkan, bahwa tidak jarang berlangsung mekanisme hubungan yang kurang harmonis antara politeknik pembina dengan PDD/AK binaannya terhadap pengelolaan anggaran yang disediakan pihak Kemdikbud. Pengelolaan anggaran oleh politeknik pembina dinilai kurang transparan, kurang obyektif, kurang sesuai peruntukkannya, dan sama sekali kurang diketahui oleh pihak pengelola PDD/AK di daerah. Pihak pengelola PDD/ AK di sejumlah daerah sama sekali tidak memiliki kewenangan dan keleluasaan terhadap pengelolaan anggaran yang ada. Bahkan kerapkali dalam pengadaan barang atau fasilitas belajar untuk kepentingan PDD/AK sepenuhnya atas inisiatif dan dropping dari politeknik pembina, tanpa melibatkan pihak pengelola PDD/AK. Tidak heran apabila dropping barang sering tidak diketahui kegunaannya dan dianggap tidak sesuai dengan kebutuhan pendidikan di PDD/AK.

\section{Saran}

Atas dasar itu sejumlah saran diajukan: pertama, diperlukan adanya upaya peninjauan kembali terhadap program studi yang diselenggarakan PDD/ AK agar sesuai dengan potensi dan kebutuhan daerah setempat. Untuk itu diperlukan pengkajian yang mendalam dan cermat guna menentukan program studi pada PDD/AK yang sinergis dengan upaya pengem- bangan potensi ekonomi wilayah/daerah; kedua, meniadakan pendirian AK tipe 'penugasan', sebaliknya dibuka kesempatan pada pihak swasta untuk turut berpartisipasi dalam penyelenggaraan AK; ketiga, dibeberapa daerah yang telah memiliki sekolah menengah kejuruan (SMK) dan/atau perguruan tinggi (Akademi/ Politeknik) dengan penyelenggaraan program studi yang serupa dengan AK, dihimbau agar AK merubah atau beralih ke program studi lain dengan melakukan pemetaan kebutuhan dan potensi ekonomi daerah di sekitarnya; keempat, diperlukan peninjauan ulang penyaluran anggaran penyiapan pendirian AK melalui politeknik pembina. Disarankan agar penyaluran anggaran pusat diberikan (baca 'dititipkan) melalui pemerintah daerah setempat (menggunakan rekening Bupati/ Walikota), dengan mekanisme hubungan pengelolaan dana yang jelas, transparan, dan sesuai kebutuhan masing-masing pihak (politeknik pembina dan PDD/ AK). Penitipan anggaran cara ini akan memunculkan komitmen dan dukungan pemerintah daerah yang tinggi untuk mengalokasikan dana dari APBD sebagai dana sharing atau dana pendampingan bagi penyiapan pendirian AK di wilayahnya; kelima, pihak Kementerian Pendidikan dan Kebudayaan hendaknya segera membentuk wadah atau tim kerja (teamwork) khusus yang bertanggungjawab langsung kepada Mendikbud, dengan tugas mulai dari menerima penghibahan lahan/ tanah dari daerah sebagai tempat bangunan/gedung AK, melakukan perencanaan pembangunan kampus AK, sampai dengan penyelesaian permasalahan dan konflik yang berlangsung di daerah terkait dengan upaya penyiapan pendirian AK ini.

\section{DAFTAR PUSTAKA}

Denison, E.F, (1962), The sources of economic growth, New York: Brookings.

Direktorat Kelembagaan dan Kerjasama, Direktorat Jenderal Pendidikan Tinggi- Kementerian Pendidikan dan Kebudayaan. 2012, "AKADEMI KOMUNITAS", Jakarta.

Gumelar, D.S. (2012). Urgensi akademi komunitas (AK) dalam sistem pendidikan nasional, Jakarta: Lokakarya Pengembangan Akademi Komunitas.

Harbison, F.H., Myers, C.A. (1964), Economics aspects of higher education, OECD.

http://www.kp3ei.go.id/in/main_ind/content2/69/68 (diunduh 130216)

http://www.kp3ei.go.id/in/main_ind/content2/69/83 (diunduh 130216)

Kepmendikbud Nomor 161 Tahun 2012.
Peraturan Presiden Nomor 32 Tahun 2011.

Schultz, T.W, (1963). The economic value of education, Columbia.

Suyanto, 2006, Dinamika pendidikan nasional, Jakarta: PSAP.

Undang-Undang Nomor 20 Tahun 2003 Tentang Sistem Pendidikan Nasional.

Undang-Undang Nomor 17 Tahun 2007 tentang rencana pembangunan jangka panjang tahun $2005-2025$.

Undang-Undang Nomor 12 Tahun 2012 tentang pendidikan tinggi.

UNDP. (2005). Human Development Report, New York: Oxford University Press.

Vaizey, J. (1987). Pendidikan di Dunia Modern, Jakarta: PT. Gunung Agung. 